\title{
ПРОСТОРОВО-ЧАСОВА ДИНАМІКА РОСЛИННОГО ПОКРИВУ ЯК ФАКТОРА ДИНАМІКИ ЧИСЕЛЬНОСТІ ШКІДЛИВИХ КОМАХ
}

\section{Рецензент - кандидат сільськогосподарських наук М. А. Піщаленко}

У статті наведені дані щзодо впливу динаміки рослинного покриву на чисельність шкідливих комах. Встановлено, щуо динаміка рослинного покриву протягом попереднього та поточного років впливає на швидкість приросту чисельності популяцій шкідників y поточному році порівняно з минулим. Кількісно ией вплив оичінено за допомогою регресійного аналізу. Для якісної оцінки характеру впливу динаміки рослинності на чисельність шкідників буряків иукрових запропоновані динамічні карти наступних видів: листової попелииі, звичайного та сірого бурякових довгоносиків, бурякової та лободової щчитоносок. Цей інструмент дозволяє візуалізувати складний характер проиесів, які визначають динаміку чисельності комах, у тому числі икідливих.

Ключові слова: буряки иукрові, динаміка, рослинність, икідники, динамічні карти.

Постановка проблеми. Проблема динаміки популяцій упродовж тривалого часу залишається провідною проблемою в екологічних дослідженнях багатьох країн світу. Особливо актуальними $\epsilon$ дослідження екологічних закономірностей динаміки популяцій, як основи екологічного прогнозування. Враховуючи те, що прогностичні моделі й досі розробляють на основі кількісних показників фітосанітарного стану будь-яких агроценозів, що вже відбувся, а також для всієї України в цілому, постає необхідність подальшого продовження дослідження екологічних закономірностей динаміки популяцій шкідників основних сільськогосподарських культур у окремих грунтовокліматичних зонах країни.

Аналіз останніх досліджень і публікацій, у яких започатковано розв'язання проблеми. Концепція ландшафтно-екологічного різноманіття, як фактору стійкого функціонування агропромислового комплексу, базується на піонерних працях М. П. Акімова [1]. Ці ідеї в аспекті вивчення комплексів шкідливої ентомофауни були творчо розвинені такими науковцями як: Л. Г. Апостоловим [2], В. П. Федоренко [6], В. О. Барсовим [3] та О. М. Сумароковим [5]. Принципи сільськогосподарської екології М. Т. Масюка [4] дають змогу підійти до розкриття складних взаємодій живих організмів, умов середовища та діяльності людини у функціонуванні агровиробництва. Серед шкідників буряків цукрових комахам належить провідне місце: вони постійно або циклічно шкодять бурякам цукровим у різних природно-кліматичних зонах України. Недостатня вивченість екологічних закономірностей динаміки популяцій окремих шкідників буряків цукрових, відсутність надійних регіональних методів прогнозування початку їх чергових популяційних циклів визначили доцільність виконання даних досліджень на користь регіону буряківництва.

Мета досліджень - визначити ландшафтноекологічні детермінанти динаміки популяцій окремих шкідників буряків цукрових.

Завдання досліджень - створити регресійні моделі, які можна застосовувати для прогнозу динаміки чисельності шкідників та оцінити їх пояснювальну здатність.

Матеріали і методи досліджень. Для визначення характеру впливу ландшафтно-екологічних показників на динаміку чисельності комах використовували регресійний аналіз, а для графічного відображення впливу динаміки рослинного покриву на стан популяцій шкідників метод динамічних карт. Латинські назви комах наведені відповідно до бази даних Fauna Europea (de Jong, Y.S.D.M. (ed.) (2013) Fauna Europaea version 2.6. Web Service available online at http://www.faunaeur.org).

Результати досліджень. Для візуалізації впливу рослинності на чисельність окремих шкідників буряків цукрових нами запропоновані динамічні карти. Приклад карти для бурякової листкової попелиці (Aphis fabae) наведений на рисунку 1. На карті представлена крива, яка відповідає усередненим за період досліджень значенням похідної індексу NDVI. Ця крива відображає типові процеси зміни рослинного покриву протягом року в межах Полтавської області. У часі рік від року та у просторі (по адміністративним районам) відбуваються відхилення від типових значень динаміки рослинності. Це варіювання може або викликати зміни стану популяцій комах, або бути результатом впливу інших факторів, які також можуть впливати на популяції комах. 


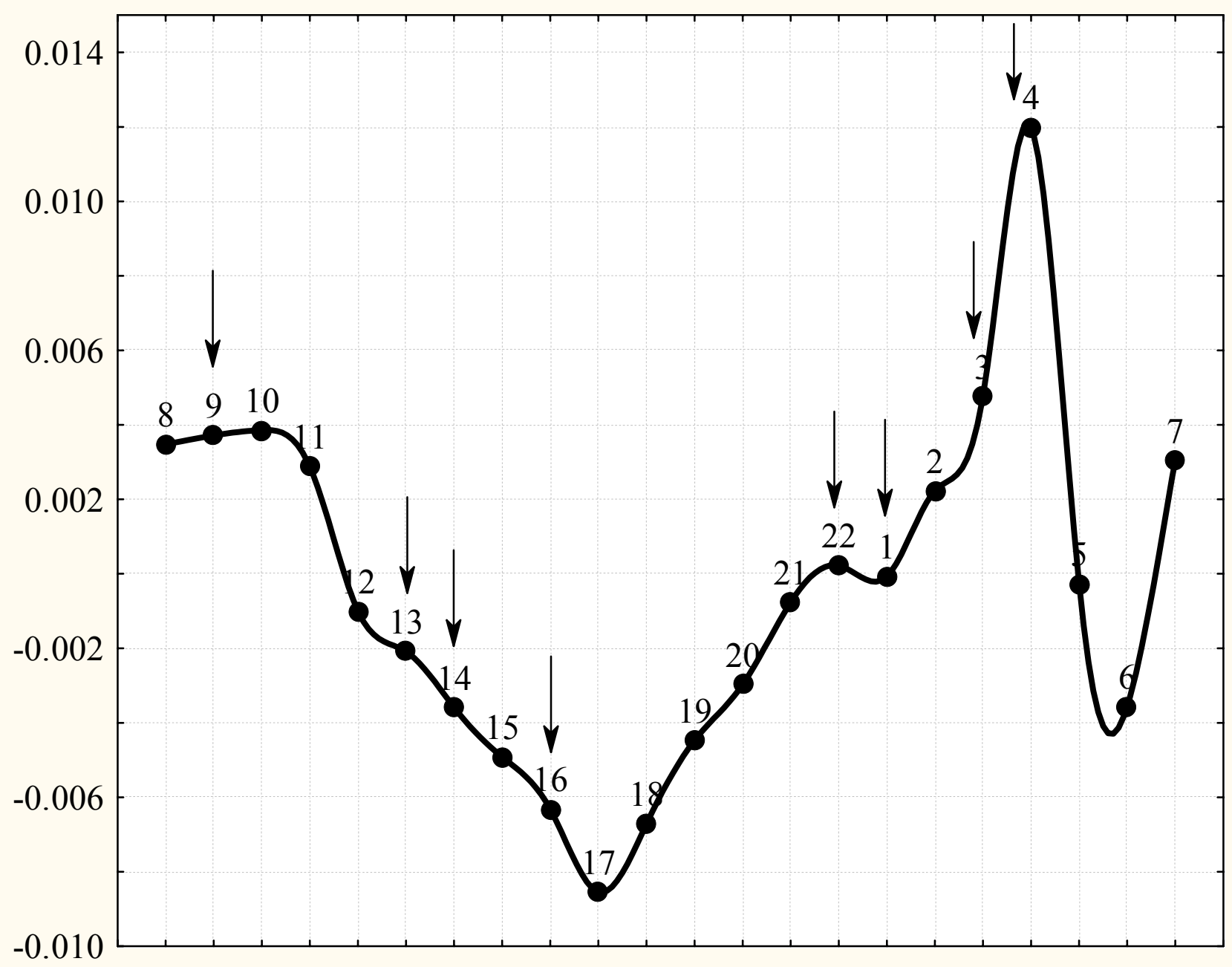

Рис. 1 Динамічна карта Aphis fabae

Умовні позначки: вісь абсцис - порядок сцен зйомки у минулому році (8-22) та у поточному році (1-7); лінією позначена усереднена за 3 роки похідна індексу NDVI; стрілками позначений знак статистично вірогідних регресійних коефіцієнтів впливу динаміки NDVI на динаміку популяцій комахи (стрілка, спрямована верх позитивний знак, вниз - негативний знак).

На карті показані стрілками знаки статистично вірогідних регресійних коефіцієнтів: позитивний знак відповідає висхідному напрямку, а негативний - низхідному напрямку. Такі позначки можна інтерпретувати так, що у випадку висхідної стрілки відхилення реальної кривої у бік підвищення спонукає до приросту швидкості зміни чисельності популяцій шкідників. Якщо у реальності буде спостерігатися відхилення у менший бік кривої NDVI, то відповідно буде зменшуватися і швидкість приросту чисельності популяцій.

У випадку низхідної стрілки зв'язок спостерігається $з$ точністю до навпаки.

Аналіз наведених даних на рисунку 1 свідчить про те, що уповільнення динамічних процесів рослинного покриву спричиняє зростання чисель- ності популяцій бурякової листкової попелиці.

Динамічна карта звичайного бурякового довгоносика (Asproparthenis punctiventris) наведена на рисунку 2.

Одержані дані свідчать про те, що активізація швидкості нарощування фітомаси протягом весни-літа минулого року призводить до створення умов, сприятливих для збільшення чисельності шкідника. Це зростання фітомаси закономірно супроводжується різким трендом до зниження в кінці літа (сцена 14 характеризується від'ємним регресійним коефіцієнтом).

Також на популяції звичайного бурякового довгоносика впливають процеси, які відбуваються в період вегетаційного спокою в кінці осені та взимку. 


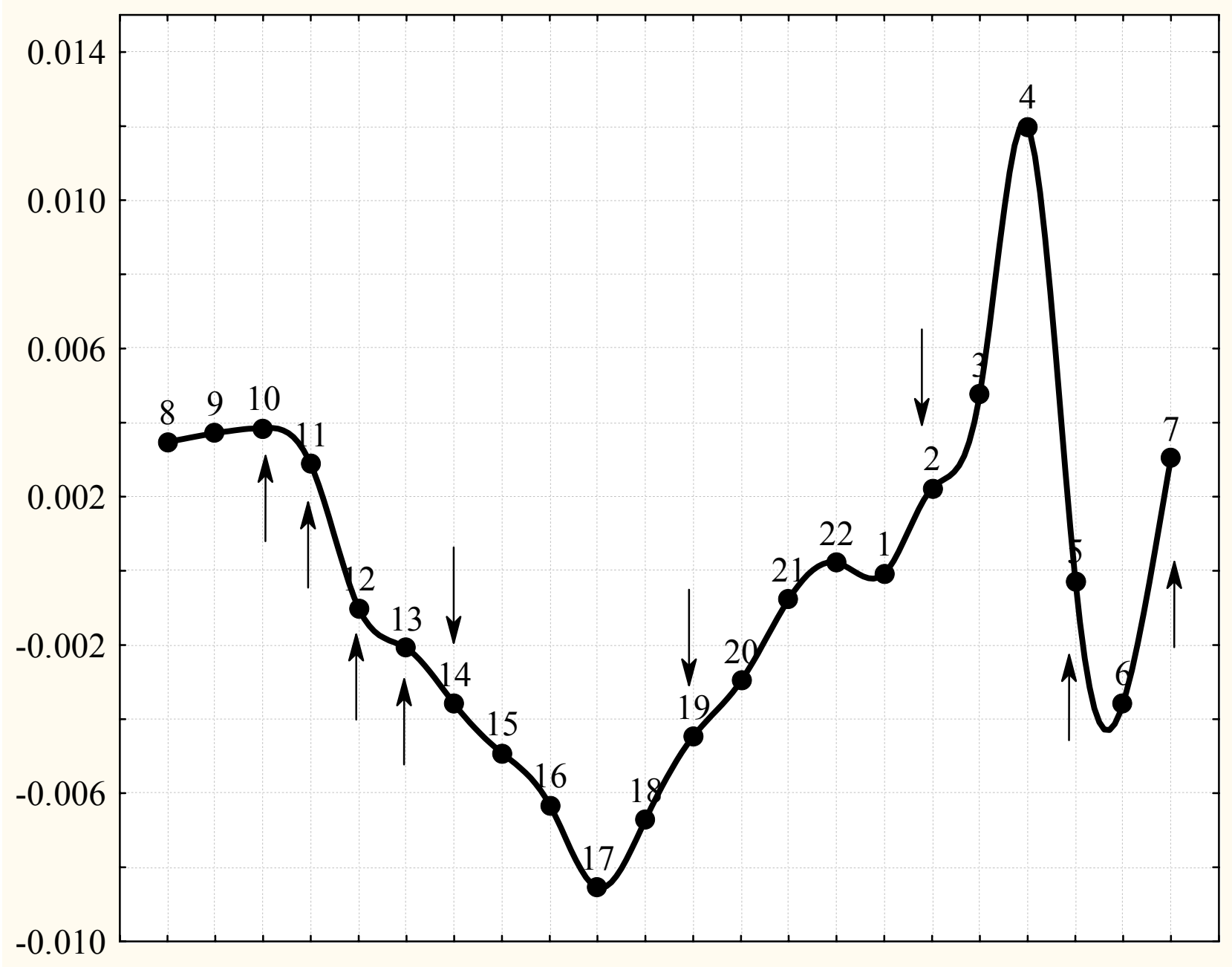

Pис. 2. Динамічна карта Asproparthenis punctiventris

Умовні позначки: вісь абсцис - порядок сцен зйомки у минулому році (8-22) та у поточному році (1-7); лінією позначена усереднена за 3 роки похідна індексу NDVI; стрілками позначений знак статистично вірогідних регресійних коефіцієнтів впливу динаміки NDVI на динаміку популяцій комахи (стрілка, спрямована верх позитивний знак, вниз - негативний знак).

Зниження інтенсивності динаміки рослинного покриву сприятиме ризикам збільшення чисельності даного шкідника. Тренди, які впливають на їх популяцію у минулому році залишаються актуальними і в поточному.

Так, активне нарощування вегетативної маси рослинами на початку весни сприяє росту чисельності популяцій звичайного бурякового довгоносика.

Таким чином, нами встановлено, що популяції звичайного бурякового довгоносика реагують на динаміку рослинного покриву.

Встановлений характер залежності за допомогою регресійного аналізу дає можливість прогнозувати динамічні процеси у популяціях цього шкідника у поточному році з урахуванням даних по динаміці варіювання рослинного покриву, встановлених за допомогою засобів дистанційного зондування Землі.

Динамічна карта бурякової та лободової щитоносок наведена на рисунку 3.

Аналіз наведених даних свідчить про те, що зниження швидкості нарощування вегетативної маси рослинним покривом влітку минулого року сприяє росту чисельності цих шкідників у поточному. Зменшення швидкості затухання фітомаси восени також підвищує ризики збільшення чисельності бурякової та лободової щитоносок.

Навесні тренд минулого року повторюється: сповільнення нарощування фітомаси рослинного покриву може спричинити збільшення чисельності бурякової та лободової щитоносок.

Динамічна карта сірого бурякового довгоносика (Tanymecus palliatus) наведена на рисунку 4. 


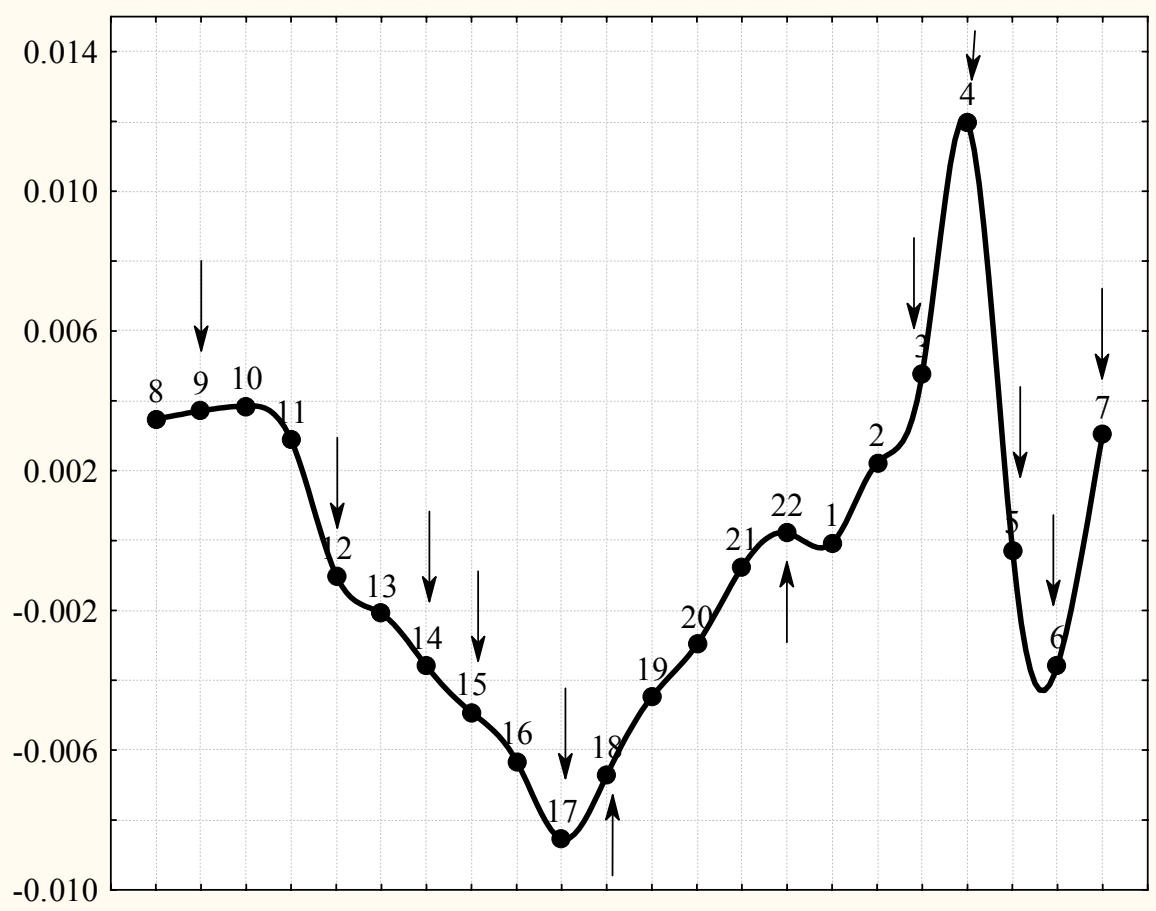

Pис. 3 Динамічна карта Cassida nebulosa ma Cassida nobilis

Умовні позначки: вісь абсцис - порядок сцен зйомки у минулому році (8-22) та у поточному році (1-7); лінією позначена усереднена за 3 роки похідна індексу NDVI; стрілками позначений знак статистично вірогідних регресійних коефіцієнтів впливу динаміки NDVI на динаміку популяцій комахи (стрілка, спрямована верх позитивний знак, вниз - негативний знак).

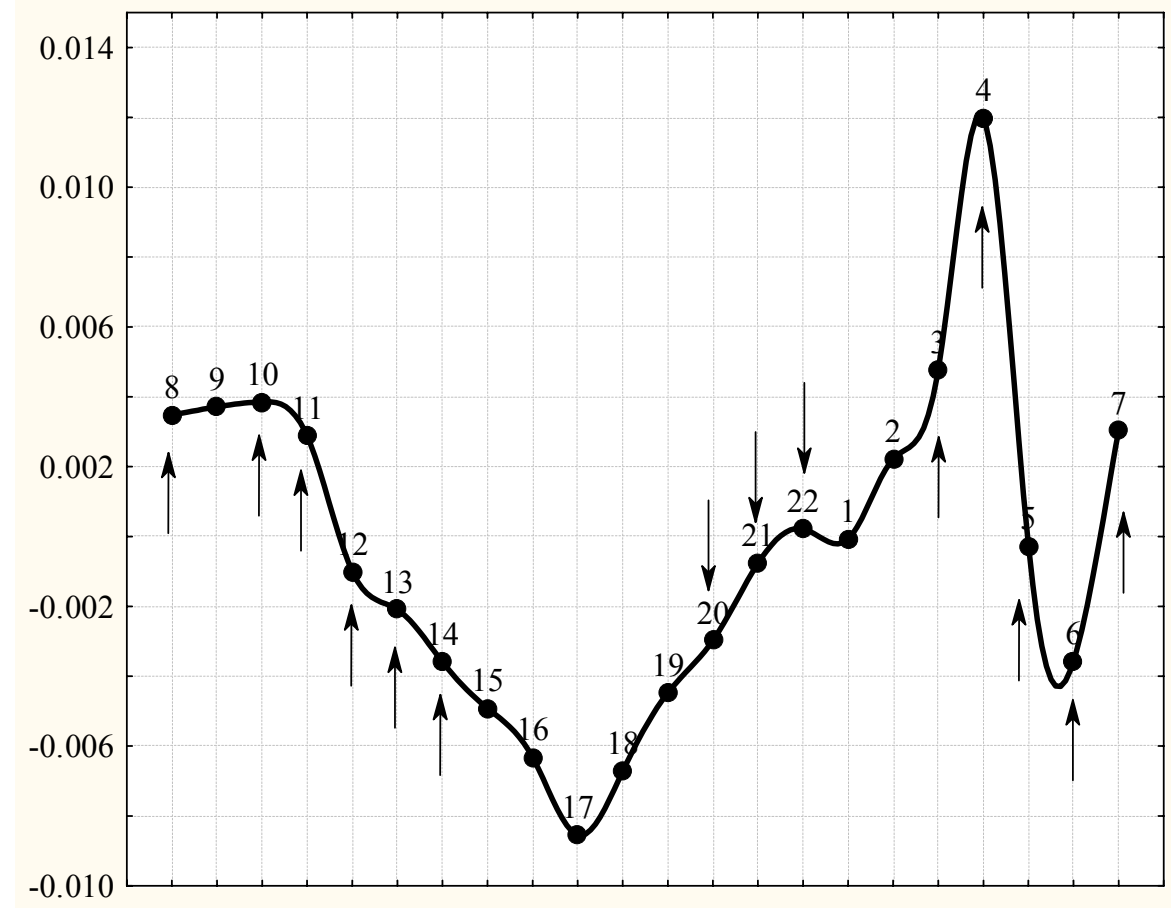

Pис. 4. Динамічна карта Tanymecus palliatus

Умовні позначки: вісь абсцис - порядок сцен зйомки у минулому році (8-22) та у поточному році (1-7); лінією позначена усереднена за 3 роки похідна індексу NDVI; стрілками позначений знак статистично вірогідних регресійних коефіцієнтів впливу динаміки NDVI на динаміку популяцій комахи (стрілка, спрямована верх позитивний знак, вниз - негативний знак). 
Аналіз даних свідчить про те, що в період 3 кінця весни до кінця літа попереднього року збільшення швидкості зростання фітомаси рослинного покриву сприяє зростанню чисельності популяцій сірого бурякового довгоносика. Навпаки, прискорення динаміки процесів в кінці осені та на початку зими минулого року призводить до депресії популяцій. Тренд по прискоренню росту чисельності сірого бурякового довгоносика внаслідок прискорення ростових процесів рослинного покриву спостерігається в ранньовесняному періоді.

\section{Висновки:}

1. Динаміка рослинного покриву протягом попереднього та поточного років впливає на швидкість приросту чисельності популяцій шкідників у даному році порівняно 3 минулим. Кількісно цей вплив оцінено за допомогою регресійного

\section{БІБЛІОГРАФІЯ}

1. Акимов М. П. Очередные задачи зооэкологического изучения искусственных лесов степной зоны Украины [сб. работ биол. ф-та Днепр. гос. ун-та.] / М. П. Акимов. - Днепропетровск, 1960. - C. 251-257.

2. Апостолов Л. Г. Вредная энтомофауна лесных биогеоценозов Центрального Приднепровья / Л. Г. Апостолов. - К. : Вища школа, 1981. - 232 с.

3. Сезонные, годовые и вызванные антропогенными факторами изменения структуры популяций почвенных и наземных беспозвоночных животных в некоторых биогеоценозах центрального степного Приднепровья / [Барсов В. А., Пилипенко А. Ф., Жуков А. В., Кульбачко Ю. Л., аналізу, в якому в якості предикторів динаміки чисельності шкідливих комах застосовані похідні індексу NDVI, встановленого за допомогою інструменту дистанційного зондування Землі MODIS.

2. У кількісному аспекті результати регресійного аналізу можуть бути застосовані для щорічного прогнозу динаміки чисельності шкідників буряку цукрового по районах Полтавської області. Регресійні моделі дозволяють пояснити 57-85 \% дисперсії динаміки чисельності досліджених видів шкідників буряку цукрового.

3. Для якісної оцінки характеру впливу динаміки рослинності на чисельність шкідників запропоновані динамічні карти. Цей інструмент дозволяє візуалізувати складний характер процесів, які визначають динаміку чисельності комах, у тому числі шкідливих.

Кисенко Т. И. ] // Вестник Днепр. ун-та. - Днепропетровск : ДГУ. - 1996. - Вып. 2. - С. 24-30.

4. Масюк Н. T. Введение в сельскохозяйственную экологию : [учеб. пособие] / Н. Т. Масюк // Днепр. с.-х. ин-т. - Днепропетровск, - 1989. $192 \mathrm{c.}$

5. Сумароков А. М. Восстановление биотического потенциала биогеоценозов при уменьшении пестицидной загрузки / А. М. Сумароков. Донецк : изд-во «Вебер», 2009. - 193 с.

6. Федоренко В. П. Ентомокомплекс на цукрових буряках / В. П. Федоренко. - К. : Аграрна наука, 1998. - 464 с. 